\title{
Cartas a José Sidrim: grafia dos afetos na Belém do Ecletismo
}

Letters to José Sidrim: graphy of affects in the Eclectic Belém

https://doi.org/10.1590/1982-02672021v29e43

\section{MATEUS CARVALHO NUNES}

https: / / orcid.org/0000-000 1-6089-071X

Universidade de Lisboa / Lisboa, Portugal

\section{PIETRA PAES BARRETO²}

https://orcid.org/0000-0003-4750-1817

Universidade Federal do Pará / Belém, PA, Brasil

RESUMO: Este trabalho analisa cartas inéditas que comunicam interesses, sentimentos e experiências estabelecidas através do relacionamento do arquiteto José Sidrim (1881-1969) com nobres personalidades da cidade de Belém que o contrataram para projetar e construir suas residências. Transcreve, também ineditamente, os relatos importantes para a pesquisa historiográfica da arquitetura e da história social da arte formado por três exemplares: carta de Guilherme Paiva (1926), de Orlando Lima (1926) e de Benedicto Passarinho (1927), escritas e enviadas a Sidrim ao término das obras. Através da compreensão da cultura escrita e das práticas de correspondências da época, este trabalho objetiva coletar e analisar informações relativas ao exercício da arquitetura, considerando seu âmbito social, as características do ofício de arquiteto em sua época e a construção de uma memória afetiva entre o proprietário da casa, o arquiteto e a edificação. Investiga-se como os relatos destas cartas narram as vivências e rituais do modo de fazer arquitetura em um momento de inovação artística e política, reflexo direto do panorama econômico pelo qual a cidade então passava. As cartas provam-se relatos

\begin{abstract}
1. Doutorando em História da Arte na Faculdade de Letras da Universidade de Lisboa (FL-UL), com período sanduíche na Faculdade de Arquitetura e Urbanismo da Universidade de São Paulo (FAU-USP). Arquiteto e Urbanista pela Universidade Federal do Pará (FAU-UFPA). Pesquisador Integrado do Instituto de História da Arte da Universidade de Lisboa (ARTIS-IHA-UL). Membro-pesquisador do Fórum Landi (FAU-UFPA), E-mail: $<$ mateusnunes@campus. ul.pt>.

2. Arquiteta e Urbanista pela Universidade Federal do Pará (FAU-UFPA), com período de intercâmbio na Faculdade de Arquitetura da Universidade de Coimbra. Especialista em Design de interiores comerciais pelo Istituto Europeo di Design em São Paulo (IED-SP). E-mail: <pietrapb@gmail. com>.
\end{abstract}


da dimensão dos impactos que a obra arquitetônica pode causar na memória e no imaginário social como declarações, epístolas afetivas, além de como produtos sociais. Consequentemente, a partir do manejo de conceitos de Roland Barthes e Gilles Deleuze, objetiva-se a reconstituição ideológica e imagética de um fragmento tanto da Belém nostálgica, moderna, de caráter idílico como de sua narrativa visual e de sua memória afetiva a partir de tal grafia dos afetos.

PALAVRAS-CHAVE: José Sidrim. Belém. Arquitetura eclética. Cartas. Afeto. Transcrição epistolar.

ABSTRACT: This paper analyzes unpublished letters that communicate interests, feelings, and experiences arising from the relationship of architect Jose Sidrim (1 88 1-1969) with distinguished characters from Belém who hired him to design and build their residencies. In a pioneering way, the work also transcribes important narratives for the social history of art and architectural historiography into a three-volume document, including letters written by Guilherme Paiva (1926), Orlando Lima (1926) and Benedicto Passarinho (1927) and sent to Sidrim at the completion of works. Based on the written culture and correspondence habits of the time, this paper aims to collect and analyze informations related to the architectural practice while considering its social field, the profile of the architect, and the construction of an affective memory between the house owner, the architect, and the building itself. For that, it investigates how these letters report experiences and rituals of the architectural practice in a moment of innovation - reflecting the economic panorama experienced by the city of Belém during that period. Beyond mere social products, the letters, being declarations, effective epistles, report the powerful impact of an architectural work in social memory and imaginary. From this writing of affections, this work aims to rebuild the image and ideology of a fragment of the nostalgic, modern, and idyllic Belém, as well as of its visual narrative and affective memory, based on the philosophical concepts postulated by Roland Barthes and Gilles Deleuze.

KEYWORDS: José Sidrim. Belém. Eclectic architecture. Letters. Affect. Letter transcription. 


\section{À GUISA DE INTRODUÇÃO}

Utilizadas como meio característico de comunicação entre os membros da elite no início do século XX, as cartas analisadas neste trabalho comunicam interesses, sentimentos e experiências estabelecidas através do relacionamento do arquiteto José Sidrim (1881 - 1969) com nobres personalidades de Belém que o contrataram para projetar e construir suas residências. Como ferramenta documental para a pesquisa historiográfica da arquitetura e da história social, a amostra das cartas endereçadas ao então expoente da arquitetura eclética na cidade é constituída por três exemplares: carta de Guilherme Paiva (1 926), de Orlando Lima (1926) e de Benedicto Passarinho (1927), escritas e enviadas a Sidrim ao término das obras.

arquiteto foi responsável por transformar os três palacetes, aqui representados e analisados através de suas respectivas cartas, em símbolos da modernidade atrelados ao ecletismo. Com o passar dos anos, tornam-se também marcas da história da cidade de Belém. Conscientes e ávidos pelo ideal de modernidade trazido pelo traço do arquiteto, os autores das cartas exprimiam não somente a gratidão com a obra concluída, serviço essencial pelo qual contrataram o arquiteto, mas também a satisfação de estabelecer com ele uma relação social.

Expressando por vezes a preocupação com o aspecto econômico e estrutural da obra, por outras, o louvor à magnitude da edificação e do trabalho de José Sidrim, as cartas demonstram o afeto e o estimo dos remetentes causados pelo fazer arquitetônico, permitindo-nos a reflexão sobre a história da posição social do arquiteto em Belém e da influência de seu trabalho na sociedade. Através da compreensão da cultura escrita e das práticas de correspondências da época, o objetivo deste trabalho é coletar e analisar informações relativas ao exercício da arquitetura, considerando seu âmbito social, as características do ofício de arquiteto em sua época e a construção de uma memória afetiva entre o proprietário da casa, o arquiteto e a edificação.

Investiga-se, neste trabalho, como estas cartas narram as vivências e rituais do modo de fazer arquitetura em um momento de inovação, reflexo direto do panorama econômico pelo qual a cidade então passava. As cartas provam-se relatos da dimensão dos impactos que a obra arquitetônica pode causar na memória e no imaginário social, como declarações, epístolas afetivas. Consequentemente, objetiva-se a reconstituição ideológica e imagética de um fragmento tanto da Belém nostálgica, moderna, de caráter idílico, como de sua narrativa visual e de sua memória afetiva a partir de tal grafia dos afetos. 
A contratação do arquiteto José Sidrim para o desenvolvimento do projeto e execução dos palacetes abordados neste artigo relaciona-se diretamente com o papel de destaque desempenhado durante sua trajetória profissional na capital paraense. Sidrim foi desenhista e agrimensor, responsável pela construção de alguns dos edifícios de maior destaque na década de 1920 em Belém.

Nascido em 1881, na cidade de Fortaleza, no Ceará, mudou-se para Belém aos 19 anos, em busca de uma nova perspectiva de vida. A cidade de Belém, desde o final do século XIX, já atraía numerosos imigrantes, pois despertava o desejo de uma vida melhor pelos frutos da até então bem-sucedida exploração e comercialização da borracha, colocando a cidade em destaque nos cenários nacional e internacional. No momento de sua chegada ao Pará, o primogênito da família Sidrim possuía apenas um curso de Desenho. ${ }^{3}$

Figura 1 - $\bigcirc$ Arquiteto José Sidrim. Fonte: Matos (2017, capa).

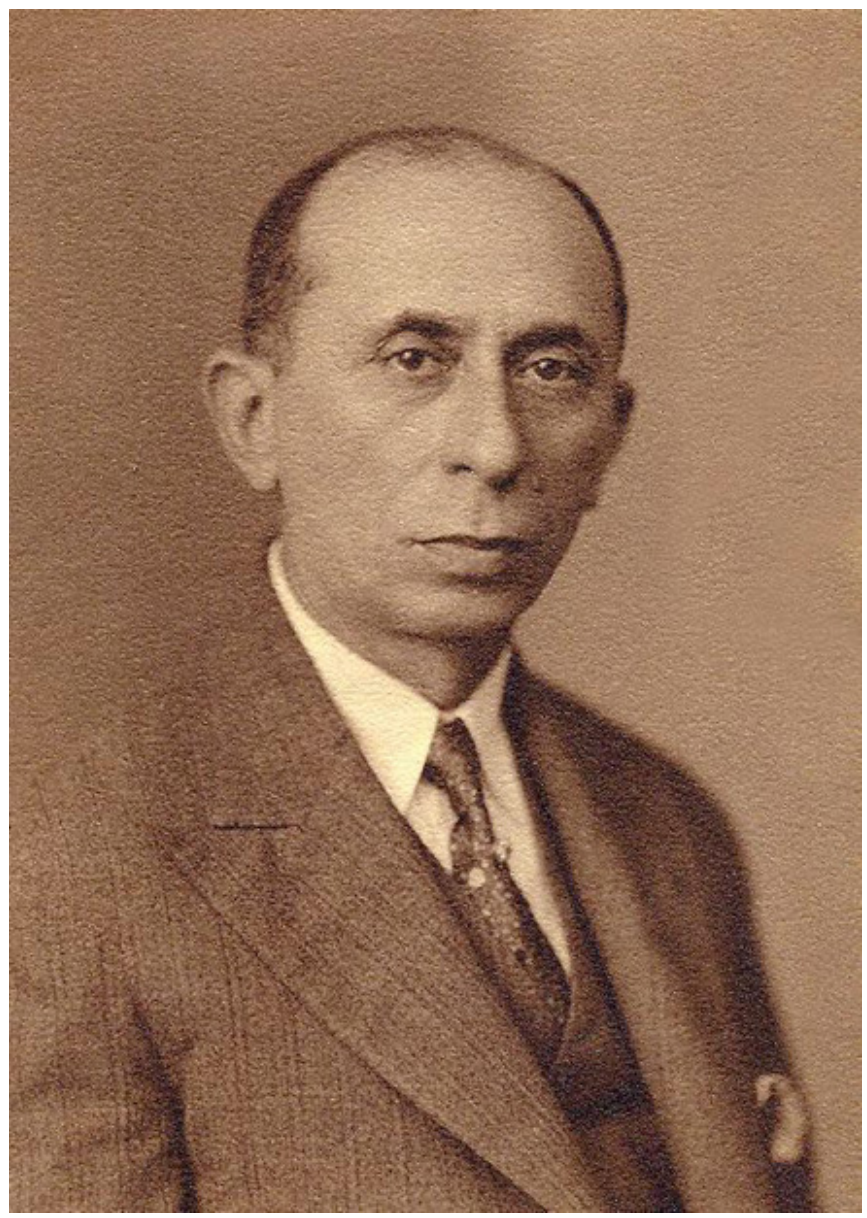


A trajetória profissional de Sidrim, após a sua chegada em Belém, é marcada pela sua admissão na Intendência Municipal, órgão que the possibilitará o estabelecimento de importantes conexões profissionais e pessoais. Iniciando o trabalho em 1903, é apenas em 1904 que se têm os primeiros registros oficiais de seu trabalho no local, publicados nos Relatórios Municipais da Administração de Antônio Lemos como Desenhista da Seção de Obras, também presentes nos relatórios de 1905, 1906, 1907 e 1908.4

É válido ressaltar que, neste período, trabalhar na administração municipal The possibilitava estar em constante contato com o que havia de mais "moderno" na produção técnica e arquitetônica em escala nacional e internacional. Após o cargo de desenhista, José Sidrim é enquadrado no cargo de Agrimensor, momento em que passa a integrar o grupo que realizará o projeto de urbanização do bairro da Pedreira; Sidrim foi responsável pelo levantamento de toda a extensão da obra e a demarcação do traçado das ruas, na qual utilizou malha ortogonal, alinhandose com a tendência urbanística da época. ${ }^{5}$

Outro fator de destaque em sua vida é a formação acadêmica, feita à distância, primeiramente como arquiteto, por meio de um curso de arquitetura por correspondência através do consulado italiano, provavelmente pela Universidade de Turim. ${ }^{6}$ Em abril de 1924, Sidrim consolida seus estudos com uma segunda formação, ainda à distância, de engenheiro arquiteto pela Escola Livre de Engenharia do Rio de Janeiro.?

Além da sua formação acadêmica à distância, primeiramente em instituição italiana e posteriormente em outra carioca, a biblioteca construída por José Sidrim durante esses anos merece destaque no desenvolvimento de sua formação técnica e de arcabouço referencial para suas próprias composições projetuais. A maior parte do acervo é de origem europeia e demonstra seu alinhamento com a produção arquitetônica do continente. Sem nunca ter saído do país ou mesmo visitado a então capital do Brasil, o arquiteto conhecia o mundo através de seus livros. A maior parte dos exemplares eram presentes de amigos e outros, assinaturas de revistas e almanaques. Como mostra Ana Léa Nassar Matos, muito dos temas presentes em seu acervo demonstram não somente o ecletismo como estilo ainda em voga na segunda década do século XX, mas também as primeiras discussões sobre o movimento moderno, como a posse do Almanach d'Architecture Moderne: Collection de L'Espirit Nouveau, de autoria do arquiteto Le Corbusier:
4. Ibid. (p. 45).

5. Gonsales (2005)

6. Matos (2017, p. 144$)$. A cidade que sedia a instituição na qual o arquiteto teria realizado a sua formação em arquitetura ainda é uma suposição, embasada por argumentos válidos. Não há provas concretas que garantem a certeza sobre a cidade de Turim; é possível que a formação por correspondência tenha sido feita em instituição de Gênova, como apresenta Ana Léa Nassar Matos.

7. Ibid. (p. 149). 
8. Ibid. (p. 158).

9. O Paiz (1925, p. 8), que reproduz trechos de notícias publicadas no jornal Estado do Pará.

10. Entrevista realizada pelos autores por telefone com a bisneta do arquiteto, profa. dra. Ana Léa Nassar Matos, em 17 de maio de 2019.

11. Matos (2017, p. 64).
De alguns livros da biblioteca José Sidrim foi possível identificar algumas procedências. Por exemplo, aqueles dedicados por João Palma Muniz (1873 - 1927): Nouvelles Annales de la Construction (dedicatória: "Ao compadre e amigo J.L. Sidrim. 1926"); - três volumes da Encyclopédie du Siécle: L' Exposition de Paris de 1900 (dedicatória: "Ao Engenheiro e Amigo Arquiteto J. Sidrim. Lembrança da [incompreensível para leitura]. Palma Muniz"); e A Decoração Na Construcção Civil (dedicatória: "Ao arqui. e eng. J. Sidrim. Palma Muniz. 1926."). E outras duas publicações identificadas pelo carimbo do "Engenheiro Civil Joaquim Lalor": a Illustrated Catalogue of Macfarlane's Castings e o quarto volume de Nouvelles Annales de La Construction. ${ }^{8}$

Apesar do curto período dedicado exclusivamente à produção de residências, os palacetes são as obras de maior destaque e reconhecimento de José Sidrim, seja pelo caráter estético e técnico do projeto seja pelo papel de transformação na identidade dos bairros nobres de Belém. Percebe-se a importância do arquiteto através da seguinte notícia do jornal $O$ Paiz, do Rio de Janeiro:

$\bigcirc$ "Estado do Pará" sob a epigraphe "Modernização da cidade" publica uma interessante estatística dos prédios em construção, do architecto José Sidrim.

Começa dizendo que no decurso do corrente anno nota-se uma febril e invulgar atividade de remodelamento do perímetro urbano da cidade, cujas edificações em estylo moderno, collocam Belém ao nível das capitais adiantadas. ${ }^{9}$

Em 1931, José Sidrim decide abandonar a construção civil por conta de problemas com a mão de obra especializada, segundo relatos de sua família. ${ }^{10} \mathrm{~A}$ dificuldade em cumprir com o orçamento inicial das obras e a complicada logística para a importação dos materiais, como o cimento vindo da Inglaterra, também foram fatores responsáveis pela saída do arquiteto do mercado. É importante lembrar que, durante este período, Belém já vivia os impactos negativos do declínio da economia gomífera. Durante os anos seguintes, até a sua morte, dedica-se a viver em seu sítio em Benfica, onde abre uma olaria. ${ }^{11}$

\section{AS CARTAS: PERSONAGENS, OBJETO HISTORIOGRÁFICO E TRANSCRIÇÃO}

Neste trabalho, analisam-se três cartas escritas por clientes proprietários de residências construídas pelo arquiteto José Sidrim (188 1-1969), considerando suas reverberações sociais e afetivas. A relevância da escolha das cartas como fonte 
historiográfica e documental acontece pela transdisciplinaridade de sua abordagem a partir de um ponto de visto fenomenológico, literário e autobiográfico, é possível analisar símbolos, nuances, imagens, imaginários e afetos. Há, nas cartas, forte subjetividade e literalidade que são importantes para a interpretação tanto das relações sociais afetivas quanto da manipulação de imagens e palavras através do afeto.

Utilizar as cartas como objeto historiográfico, juntamente com os conceitos metodológicos escolhidos neste trabalho, possibilita uma análise plural do fato, possibilitando que se escape do hermetismo de outras fontes documentais interpretadas como fato ou real acontecido, o que permite "resgatar possibilidades verossímeis que expressam como as pessoas agiam, pensavam, o que temiam, o que desejavam", 12 ou seja, "os tais fatos narrados não se apresentam como dados acontecidos, mas como possibilidades, como posturas de comportamento e sensibilidade, dotadas de credibilidade e significância". ${ }^{13}$

As três cartas analisadas, destinadas a José Sidrim, remetidas por Orlando Lima (em 1926), Guilherme Paiva (em 1926) e Benedicto Passarinho (em 1927), são do acervo da arquiteta e historiadora Ana Léa Matos Nassar, autora da tese de doutorado em História intitulada "José Sidrim (1881-1969): um capítulo da biografia de Belém", ${ }^{14}$ mais importante trabalho historiográfico sobre a vida e obra do arquiteto. As cartas foram publicadas em sua tese, porém as transcrições e análise segundo a perspectiva proposta neste trabalho são inéditas.

Os autores das cartas, então proprietários das casas construídas por Sidrim, eram membros da elite intelectual e social da cidade na época. As cartas provavelmente não teriam sido escritas em um cenário social diferente. ${ }^{15} \mathrm{~A}$ predileção por Sidrim no momento da escolha do arquiteto que iria projetar e construir suas casas e a escritura destas - como um dispositivo de protocolo social - são reiterações do papel que os proprietários detinham na sociedade. Adotamos as cartas pessoais analisadas como "artefatos autobiográficos": 16

Artefatos, pois são produzidas intencionalmente a partir de uma certa performatividade comunicativa, ou seja, são escritas de modo a comunicar informações, sentimentos e formas de tratamentos sociais de forma seletiva, sendo esta seleção consciente ou inconscientemente feita. São produções que operam como dispositivos sociais, evidenciando principalmente, neste caso, não apenas as relações de amizade entre os remetentes e o destinatário, mas as relações hierárquicas, de influência e de poder que os contratantes-autores e o arquiteto contratado desempenhavam na sociedade da elite de Belém no início do século XX.

Autobiográficos, porque expõem, ao selecionar suas ferramentas compositivas textuais, características relevantes do autor e de seu contexto, seja
12. Martins (2011, p. 68).

13. Ibid., loc. cit.

14. Matos (2017)

15. Como destacam Gómez e Sáez (2016, p. 185): "Em síntese, a história social da escritura nos chega através de uma lente bifocal que tem em uma de suas caras o uso da escritura como instrumento de poder e na outra as marcas do acesso privado à habilidade de escrever por parte das classes populares".

16. Lima (2010, p. 213). 
17. Nunes (2019).

18. Deleuze (2007, p. 195).

19. Deleuze e Guattari (1992, p. 227-228).

20. Barthes (2018).

21. Ibid., p. 65 . seus afetos, seu temperamento, seja sua posição social, seu intelecto, sua erudição, seus posicionamentos ético e político etc. ${ }^{17}$ As cartas evidenciam, também, a forma de olhar e interpretar as obras a partir do ponto de vista do cliente. Observa-se que em cada carta há ênfase em um determinado quesito da edificação, seja ele os aspectos estéticos, financeiros ou logísticos. $\bigcirc$ dispositivo autobiográfico da "escrileitura" (tanto das cartas quanto da arquitetura das casas) será melhor apresentado a seguir.

Analisamos as cartas sob duas matrizes teóricas: sob o conceito de "afeto" em Gilles Deleuze - também abordado na obra conjunta com Félix Guattari - e de "biografema" de Roland Barthes. Deleuze constrói o conceito de afeto a partir de Espinosa, ao entendê-lo como uma força afirmativa e compositiva de ideias. $\mathrm{Na}$ estrutura compositiva de ideias e imagens, há um fluxo dialético de manejo e, em suas intersecções, há o afeto:

O circuito completo compreende pois o choque sensorial que nos eleva das imagens ao pensamento consciente, e depois o pensamento por figuras que nos leva às imagens e torna a nos causar um choque afetivo. Fazer coexistir os dois, juntar o grau mais alto de consciência ao nível mais profundo do inconsciente: 0 autômato dialético. ${ }^{18}$

O afeto, portanto, constitui engrenagem essencial na operação de expressão e nos processos artísticos, em suas multiplicidades e singularidades operativas:

É de toda arte que seria preciso dizer: o artista é mostrador de afectos, inventor de afectos, criador de afectos, em relação com os seus perceptos ou as visões que nos dá. Não é somente em sua obra que ele os cria, ele os dá para nós e nos faz transformar-nos com ele, ele nos apanha no composto. ${ }^{19}$

Este mesmo afeto, quando relacionado à escritura de cartas, objeto deste trabalho, relaciona-se com a visão de Barthes sobre a carta de amor em Fragmentos de um discurso amoroso:20 "CARTA. A figura visa à dialética particular da carta de amor, ao mesmo tempo vazia (codificada) e expressiva (cheia de vontade de significar o desejo)". ${ }^{21}$ As cartas funcionam não somente como correspondência privada, mas também como outorga pública, dispositivo de protocolo social do reconhecimento afetuoso pelo trabalho desenvolvido naquele contexto social. Sobre a leitura das cartas como produtos sociais, Gómez e Sáez destacam: 
A concepção de escritura como instrumento do poder e expressão da mesma estrutura social é paralela à tese de Foucault sobre o documento / monumento, tão oposta à matéria inerte dos positivistas. Sob essa perspectiva, o documento/a escritura são estudados como um "produto da sociedade, que os fabricou segundo as relações de força que nela detinham o poder. É, por dizê-lo com outras palavras, o produto de uma certa orientação da história". Palavras similares às que emprega Jacques Le Goff quando define o documento não somente como consequência de uma situação histórica dada, mas, sobretudo, enquanto produto orientado da mesma, isto é, "resultado do esforço feito pelas sociedades históricas para impor ao futuro - querendo ou não - uma imagem de si mesmas". Por dizê-lo também com a voz de Roger Chartier, os "materiais-documentos obedecem a procedimentos de construção nos quais se empregam conceitos e obsessões de seus produtores e onde se marcam as regras da escritura particulares ao gênero que sinaliza o texto". ${ }^{22}$

Estas cartas são salpicadas de detalhes biográficos, o que Barthes chama de "biografemas", conceito exposto pela primeira vez no prefácio de sua obra Sade, Fourier, Loyola ${ }^{23}$ e retomado em La chambre claire ${ }^{24}$ (A câmara clara). Constitui-se como uma ferramenta de escritura guiada por um processo seletivo, lida e escrita a partir de detalhes biográficos:

Do mesmo modo, gosto de certos traços biográficos que, na vida de um escritor, me encantam tanto quanto certas fotografias; chamei estes traços de 'biografemas'; a Fotografia tem com a História a mesma relação que o biografema tem com a biografia. ${ }^{25}$

Quanto à decisão de transcrição a partir de critérios paleográficos e diplomáticos, tal escolha ocorre pois a disseminação e análise do texto das cartas per se é facilitada a partir de sua consideração também como objetos documentais de caráter historiográfico, de modo a enfatizar a função social da escrita numa abordagem histórico-social. ${ }^{26}$ Esta visão paleográfica-historiográfica, que propõe a transcrição apresentada paralelamente à imagem do documento, obteve destaque no século XX, principalmente com as obras de Giorgio Cencetti, ${ }^{27}$ István Hajnal, ${ }^{28}$ Armando Petrucci e Alessandro Pratesi. ${ }^{29}$ Nas transcrições das cartas, optamos por não modernizar ou alterar o texto grafado. As transliterações, pontuações e escolhas ortográficas mantêm-se como estão nas cartas (sic passim), podendo ser observadas nas imagens de suas digitalizações que as acompanham. Apenas as assinaturas foram substituídas por indicações, entre colchetes, ao final das cartas.
22. Gómez e Sáez, op. cit., p. 185-186, itálico do autor.

23. Barthes (2005).

24. Barthes (1980)

25. Barthes (2017, p. 32).

26. Gómez e Sáez, op. cit.

27. Cencetti (1948).

28. Hajnal (1934).

29. Petrucci e Pratesi (1998) 
30. Sobre o desenvolvimento neste período histórico em Belém, recomendamos: Sarges (2010); Castro (2010); Sarges e Lacerda (2016); Figueiredo (1997); Bahia (2016); Soares (2008); Alcântara, Brito e Sanjad (2016); Nunes (2017).

\section{CENÁRIO SOCIAL E URBANO DA CIDADE DE BELÉM}

$\bigcirc$ período em que as cartas destinadas ao arquiteto José Sidrim foram escritas representa um momento de transição na cidade de Belém. Para entendê-lo, é necessário analisar as duas décadas que antecederam os anos de 1925 e 1926, anos de escritura das cartas.

A transição entre o fim do século XIX e primeira década do século XX na região Norte é marcada por período áureo de desenvolvimento, fruto da bemaventurada exploração gomífera. ${ }^{30}$ Um grande número de empresas estrangeiras investiu na capital, acarretando a atração de imigrantes, a urbanização do centro da cidade e a construção de equipamentos públicos e prédios de destaque que marcam o período que ficou conhecido como Belle Époque. A Paris n'América, como era então chamada a cidade de Belém, possuía relação direta com as grandes capitais europeias em seus fluxos culturais, sociais, ideológicos ou econômicos.

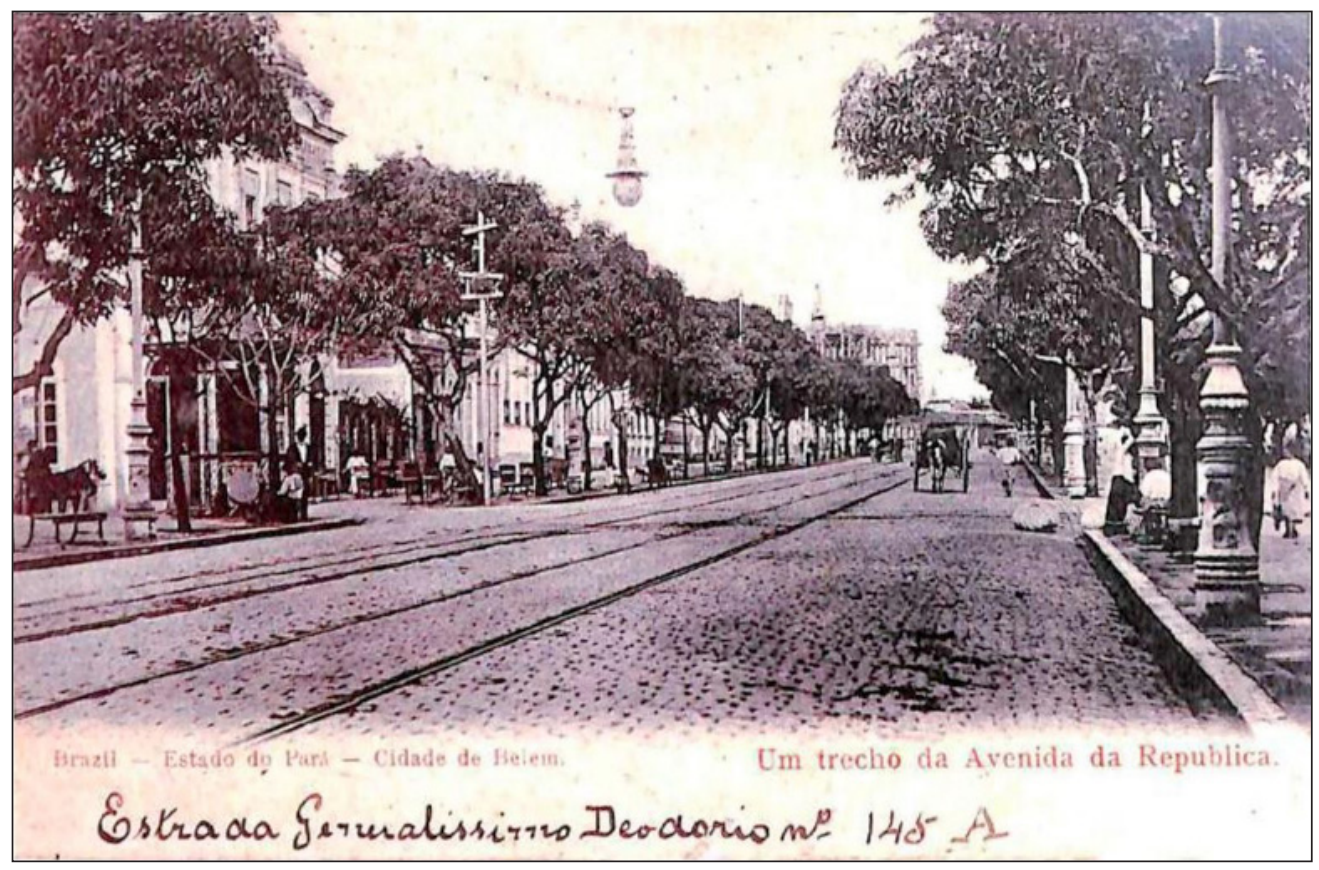

Figura 2 - Avenida da República (atualmente Avenida Presidente Vargas) com a Rua da Paciência (hoje Rua Carlos Gomes). Piso em pedra de liós, trilho para o bonde elétrico, poste de iluminação em ferro e as famosas mangueiras, árvores simbólicas da cidade. Fonte: Belém da Saudade... (1998, p. 90). 


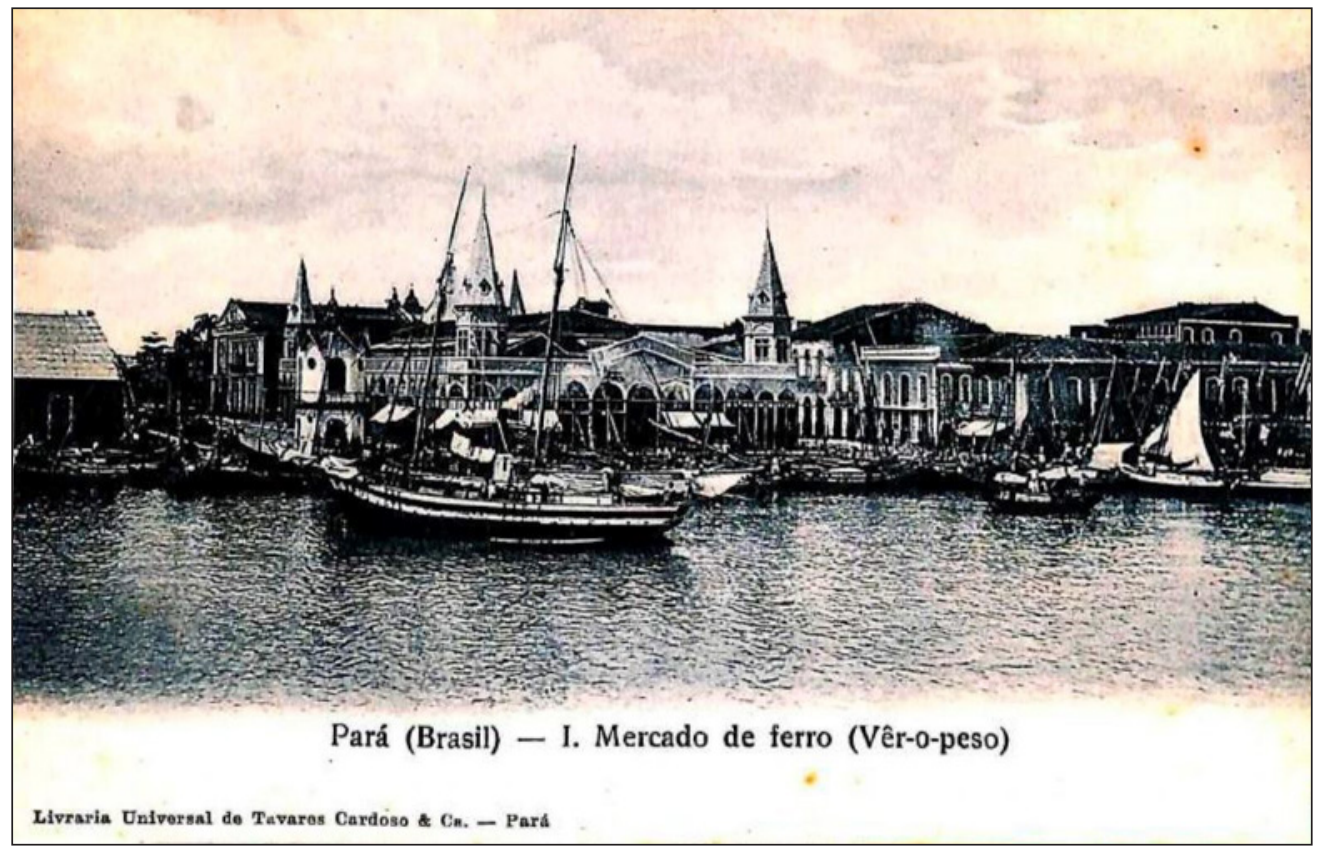

Figura 3 - Doca do Ver-o-Peso e Mercado de Ferro. Entreposto comercial movimentadíssimo na época, cercado de sedes de representantes mundiais movidos pelo comércio da borracha. Fonte: Belém da Saudade... (1998, p. 50).

Com a instituição da República, a paisagem urbana é reconstruída e, junto a ela, uma nova sociedade burguesa desponta. Neste momento, o ecletismo é adotado como estilo arquitetônico predominante da elite, considerado o símbolo de modernidade e progresso na região. Torna-se, então, a expressão arquitetônica de uma sociedade que busca afirmação e reconhecimento, adotando, contraditoriamente, a estética do passado europeu como símbolo do progresso.

Durante a intendência de Antônio Lemos (de 1897 a 1911), o centro histórico da cidade é negligenciado e o investimento é destinado às áreas portuárias e seus entornos, conforme aponta a historiadora Karol Gilet: "O planejamento urbano adotado por Lemos optou pelo abandono do centro histórico e por uma remodelação da área adjacente ao porto mas também resolveu ocupar áreas não utilizadas, consideradas enormes vazios no conjunto urbano de Belém". ${ }^{31}$ Esta decisão política apresentou certos benefícios, mas também acarretou no baixo aproveitamento destas áreas, corroborando para o período de recessão que se instalaria em Belém nos anos seguintes. Todavia, já havia sido instalado na sociedade a influência da reuropeização ${ }^{32}$ dos costumes da sociedade.

Foi neste contexto que cresceu a demanda da burguesia paraense por uma nova forma de habitar. $\bigcirc$ "morar à francesa" foi o estilo adotado por esse grupo e 
33. Lemos (1999, p. 34).

34. Pereira (2007).

35. Lima, Nunes e Eiró (2018).

36. Paes Barreto (2018, p. $10)$.

37. Soares (2008, p. 108). o palacete como tipo arquitetônico predileto devido à sua imponência. Formalmente, eles apresentam mais de um pavimento, com generosos recuos, jardins em destaques e ambientes para atividades específicas, demonstrando, de forma simbólica, o glamour burguês conscientemente expresso em sua arquitetura: "O palacete PL é a novidade rica, raramente térrea, propiciando quase sempre o "morar à francesa" e procura, sobretudo, uma quantidade muito grande de acomodações de modo que sejam evitadas, sempre que possível, superposições das atividades $[\ldots]^{\prime \prime}{ }^{33}$

A escolha do ecletismo como estilo arquitetônico mais utilizado nas residências de tipologia palaciana está relacionada à necessidade da incorporação de novos programas e funções à então forma de morar da burguesia. Nas produções arquitetônicas dos profissionais que atuaram no período verifica-se, além da coexistência de técnicas, programas e estilos do passado e do presente, a persistência da tradição colonial entrelaçada com o desejo de modernização presente no imaginário da sociedade burguesa. ${ }^{34} \mathrm{~A}$ predileção pelo ecletismo na arquitetura, assim como a execução de obras de caráter higienista e o estabelecimento de infraestrutura na escala urbanística, são símbolos essenciais da modernização da cidade de Belém e do orgulho declarado do desenvolvimento da cidade a partir dos ideais europeus. ${ }^{35}$

\section{O CÍRCULO SOCIAL DOS AUTORES}

Antes da análise das cartas, é importante compreender a relação social estabelecida pelos seus autores e suas motivações na escolha de José Sidrim como arquiteto, bem como do tipo palaciano para suas moradias.

Orlando Lima, Guilherme Paiva e Benedicto Passarinho eram membros de destaque na sociedade de Belém não apenas pela ativa participação na vida social da cidade, mas, principalmente, pelo reconhecimento profissional que conquistaram durante os anos. Dentre as similaridades estabelecida por eles, percebemos a relação direta com a forma de morar europeia, refletida no programa de necessidades de suas residências. Orlando Lima e Guilherme Paiva realizaram a sua formação acadêmica no continente europeu; já Benedicto matriculou suas filhas em um renomado colégio interno francês (Le Collège Feminin de Bouffémont) nos arredores de Paris e frequentemente passava temporadas na França para visitar as meninas. ${ }^{36}$

Segundo os relatos de Karol Gillet em sua dissertação "As formas de morar na Belém da Belle-Époque", ${ }^{37}$ o número de empresas e de profissionais da 
construção civil em Belém era extenso; todavia, a maioria deles eram apenas engenheiros. José Sidrim, então, foi um dos primeiros profissionais com formação especializada em arquitetura por uma escola europeia que atua efetivamente durante a década de 1920 na capital paraense. Um de seus contemporâneos será o arquiteto italiano Filinto Santoro, proveniente da Real Academia de Nápoles e autor de projetos de prédios de destaque em Belém. Outro nome presente na produção arquitetônica da cidade é o do arquiteto José Castro Figueiredo, embora sua produção se concentre no final do século XIX, como o Palacete Faciola em 1895 e o Instituto Paraense de Educandos Artífices, ${ }^{38}$ posteriormente batizado de Instituto Lauro Sodré e, atualmente, Tribunal de Justiça do Estado.

Todavia, como fato distintivo citado pelos autores-proprietários, a qualidade técnica do trabalho de José Sidrim impressiona. $\bigcirc$ rigor com que todos os elementos do projeto eram desenhados por ele e executados pela sua equipe de profissionais merece destaque. Assim, alguns elementos arquitetônicos tornam-se sua marca registrada, como a suntuosa escada de madeira localizada em um volume destacado nas fachadas laterais dos seus palacetes. Apesar de não ter o hábito de usar elementos arquitetônicos pré-moldados, o uso de catálogos será recorrente na escolha de louças, azulejos e ladrilhos para as residências, estes comumente importados.

Outra semelhança estabelecida entre os três proprietários era sua participação ativa na cena religiosa de Belém. Em 1909, iniciou-se a construção da atual Basílica de Nossa Senhora de Nazaré, ${ }^{39}$ um dos mais importantes edifícios religiosos da cidade. Para a realização da obra, foi necessária a angariação de doações de vários fiéis; dentre eles, encontram-se Orlando Lima, Guilherme Paiva e Benedicto Passarinho, todos com vitrais nas capelas laterais da igreja em sua homenagem (Figuras 4, 5 e 6). 
Figura 4 - Vitral dedicado a Orlando Lima, na Basílica de Nossa Senhora de Nazaré. Foto: Mateus Nunes.

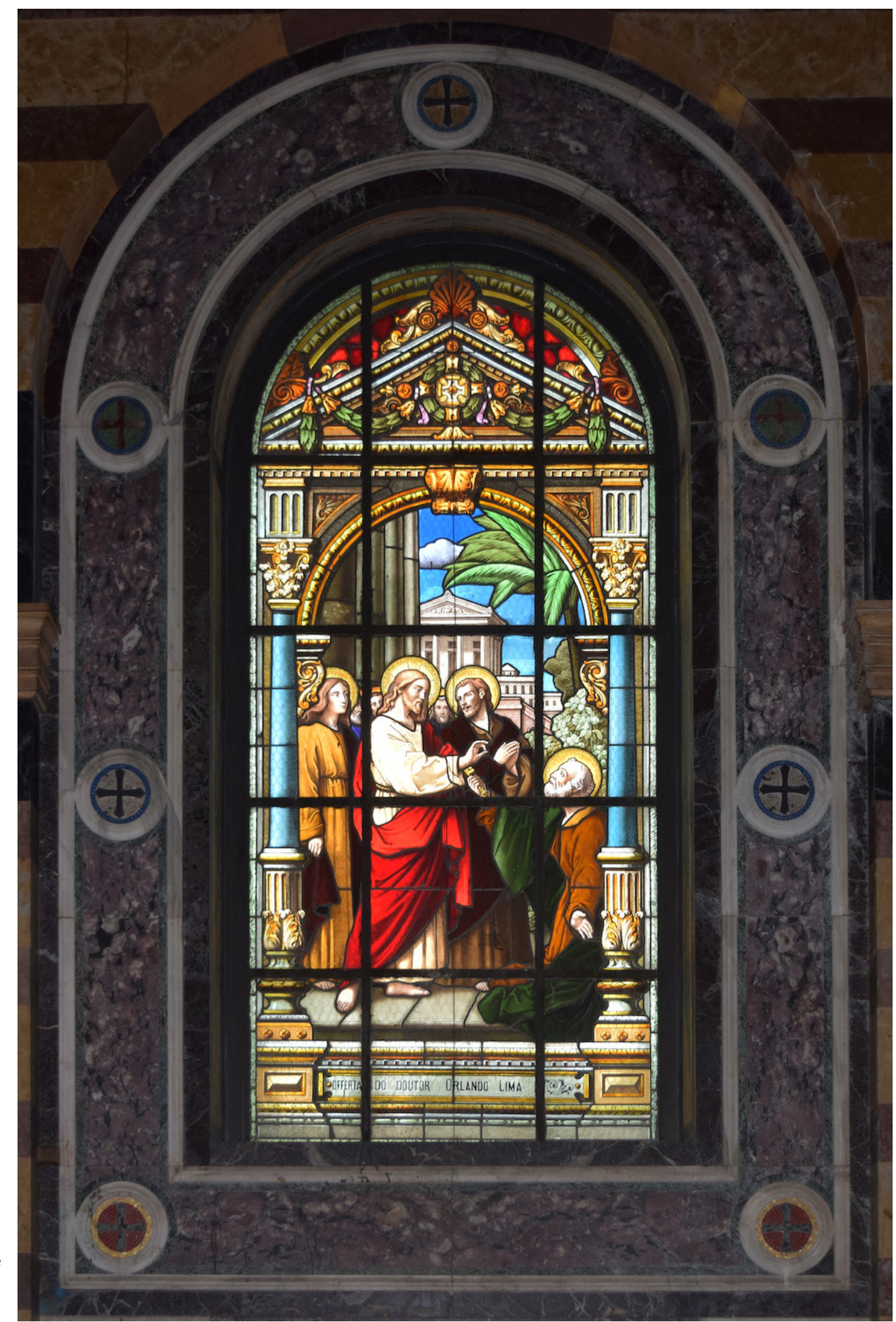




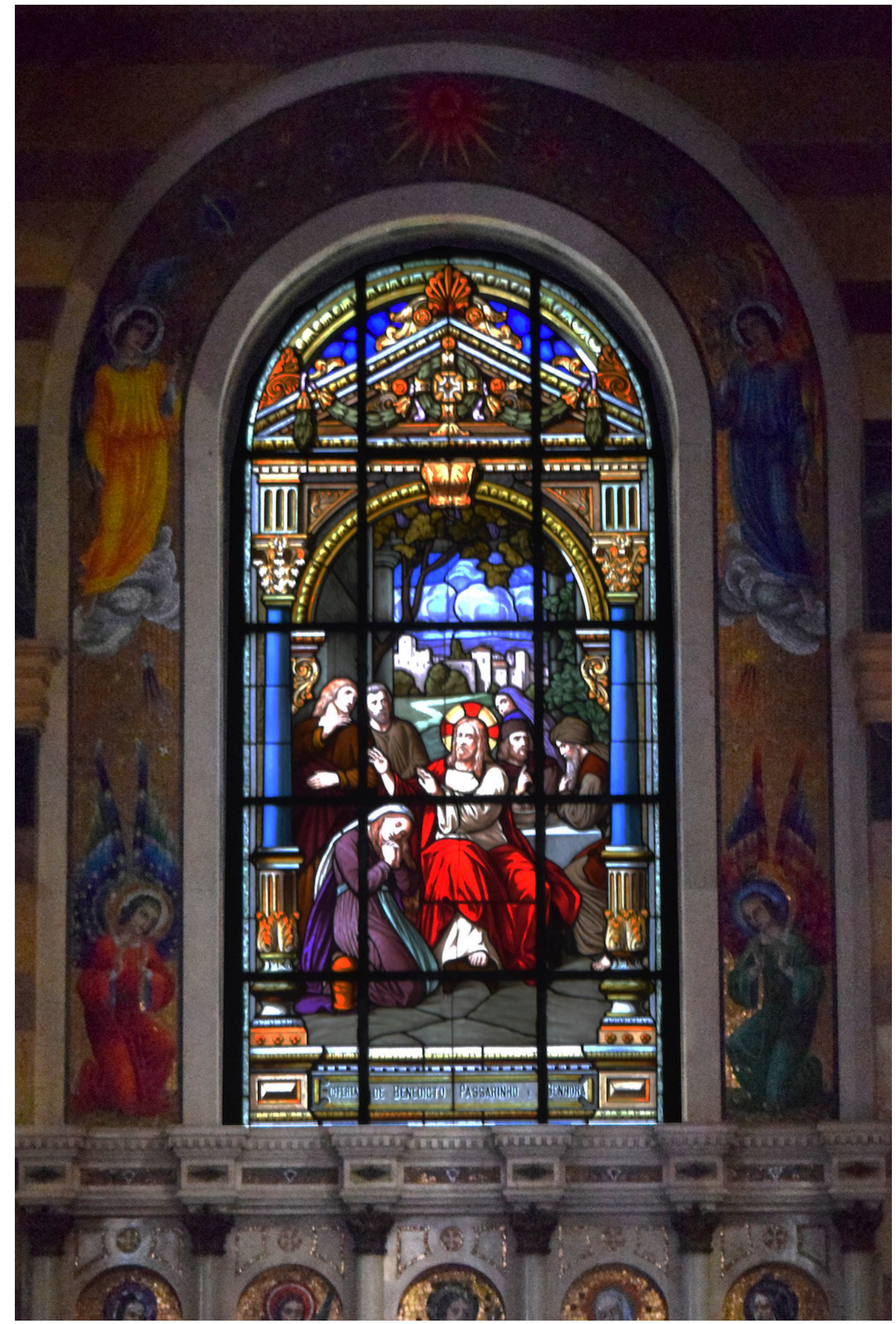

Figura 5 - Vitral dedicado a Benedicto e Aurélia Passarinho, na Basílica de Nossa Senhora de Nazaré. Foto: Mateus Nunes. 
Figura 6 - Vitral dedicado à família de Guilherme Paiva, na Basílica de Nossa Senhora de Nazaré. Foto: Mateus Nunes.

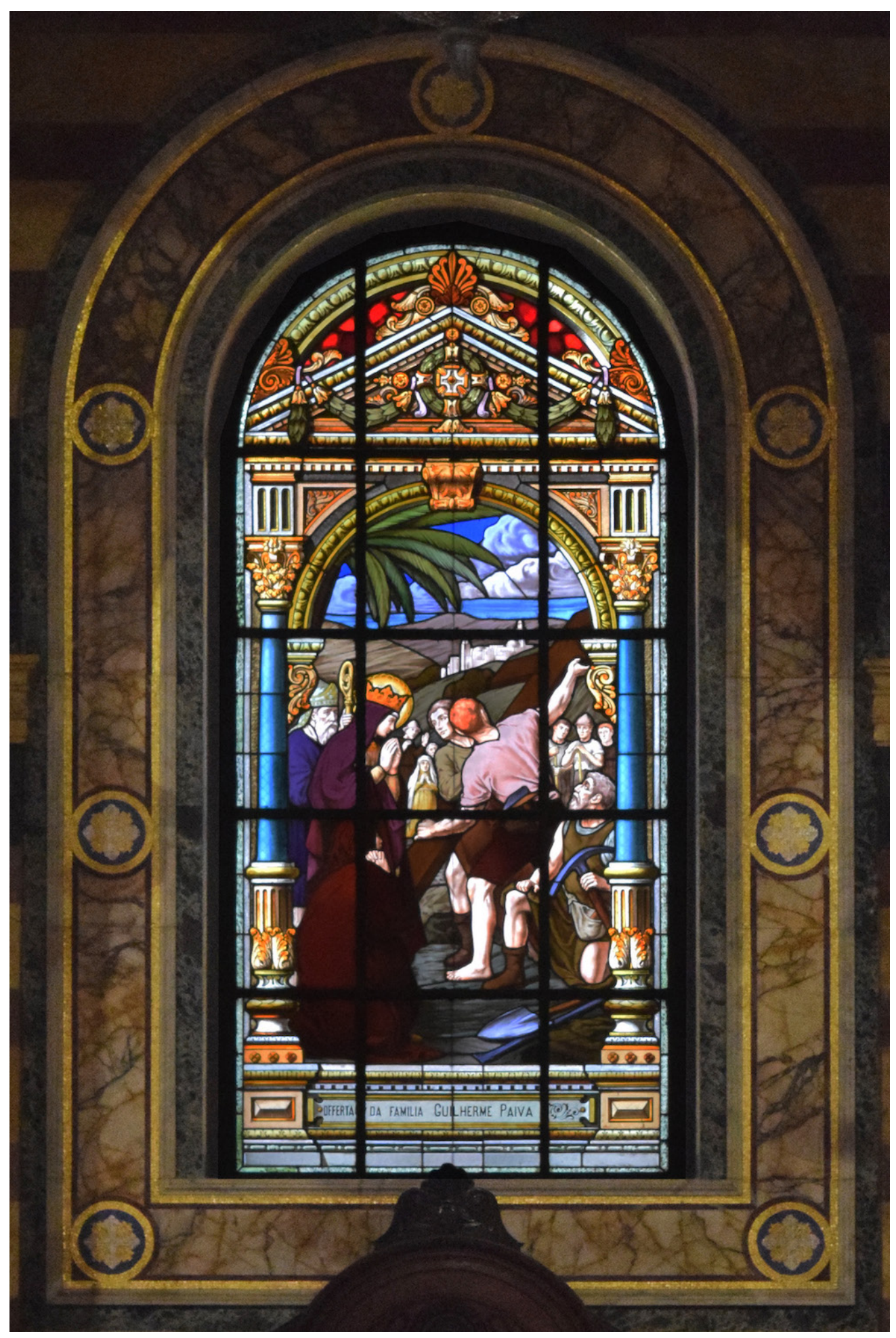


Os projetos privados foram recorrentes durante a década de 1920 para o arquiteto José Sidrim, que havia se empenhado em obras institucionais e públicas durante outros momentos. $\bigcirc$ grande número de contratos, sobretudo residenciais, além da presença recorrente em concursos, foi essencial para a construção do destaque e da importância do arquiteto na época.

\section{AS CARTAS AO ARQUITETO E SEUS AUTORES}

\section{Orlando Lima}

Argemiro Orlando Pereira Lima era médico ginecologista e obstetra, membro da Academia Nacional de Medicina, das Academias Paraense e Amazonense de Letras e diretor da Santa Casa de Misericórdia de Belém. ${ }^{40}$ Citado em diversos eventos sociais e políticos dos jornais da primeira metade do século XX, é possível notar a participação ativa do médico na vida social da capital. ${ }^{41} \bigcirc$ primeiro contato com o arquiteto e construtor José Sidrim foi durante a construção da Maternidade e do Hospital Infantil da instituição que Orlando era diretor. Com o estreitamento da relação, surgiu então o convite para a construção da residência do médico na Travessa Dr. Moraes, no bairro de Nazaré, área bastante urbanizada e onde se localizam diversos palacetes na cidade.
40. Matos (2017, p. 262).

41. Em Jornal Estado do Pará (1914, p. 14) são citados os nomes do médico Orlando Lima e do engenheiro Guilherme Paiva como paraninfos de uma cerimônia da Intendência Municipal. 


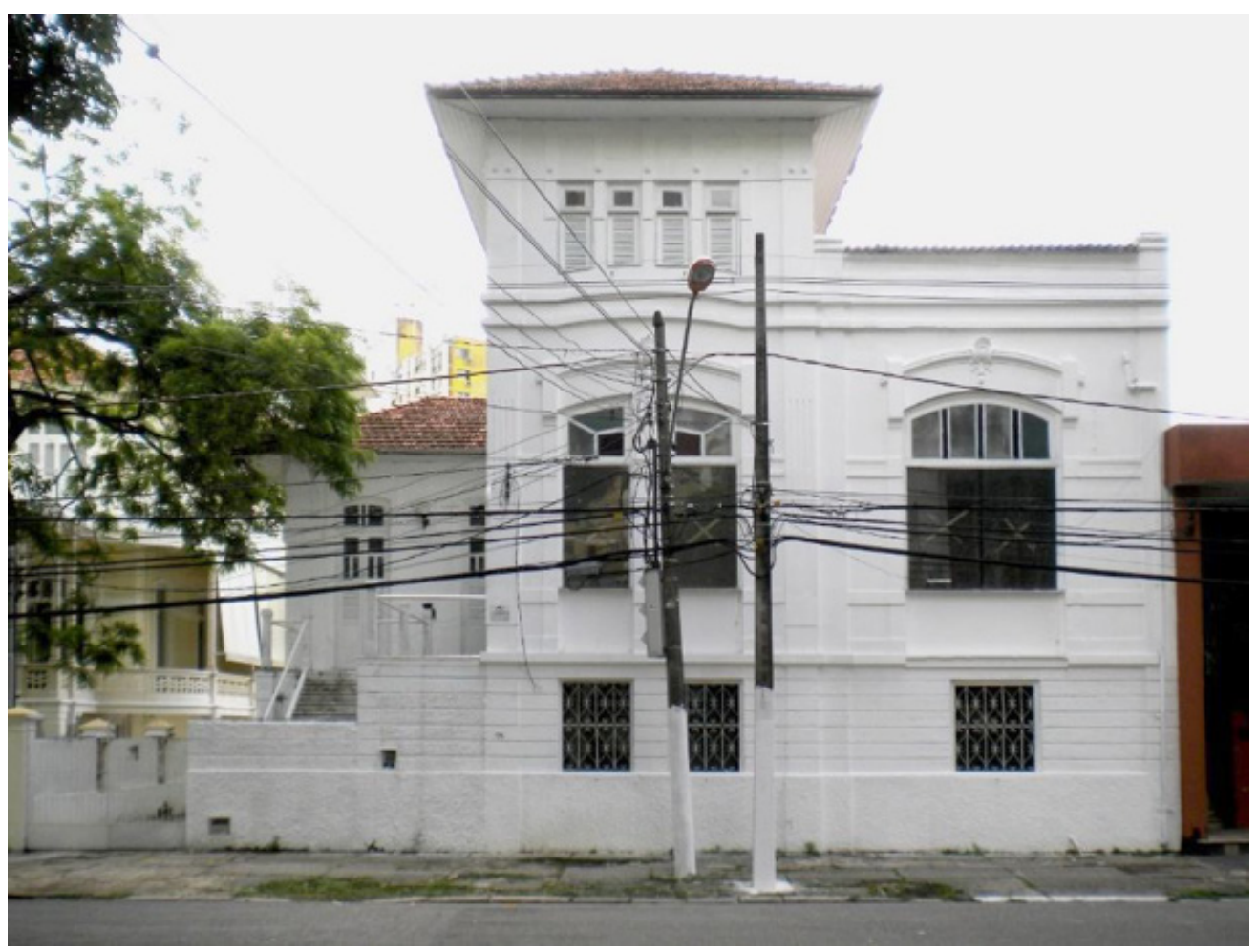

Figura 7 - Palacete Orlando Lima. Em primeiro plano, porão habitável e janelas do primeiro pavimento. Ao fundo, escada de acesso ao setor social. Foto: Dulcilia Acatauassu Nunes.

Devido às dimensões reduzidas do terreno em que o palacete foi construído, se comparado aos padrões residenciais da elite de Belém, a residência possui uma das suas duas laterais geminadas, de tal maneira que o afastamento ocorre em apenas um dos lados. Com um programa de necessidades complexo, ele apresenta um pavimento térreo com porão habitável e um pavimento superior, ambos com ambientes sociais, íntimos e de serviço. A setorização do pavimento térreo é composta por ambientes para o lazer, como biblioteca e sala de bilhar, e um salão com conexão direta ao primeiro pavimento. Dois pequenos quartos na área íntima e um espaço para lavanderia e engomados compõem o porão. $\bigcirc$ pavimento acima pode ser acessado pela escada lateral, levando o visitante diretamente à varanda, em que é possível acessar a sala de estar, a sala de jantar ou um pequeno vestíbulo. Cozinha, copa e sala de almoço fazem parte do setor de serviço. Já no setor íntimo, três dormitórios, sala de vestir, casa de banho e um pequeno oratório completam o palacete eclético.

oratório presente na residência demonstra a religiosidade de seus moradores. A família de Orlando Lima foi uma das financiadoras da construção 
da Basílica de Nossa Senhora de Nazaré, possuindo um dentre os cinquenta e quatro vitrais da lgreja em sua homenagem.

A carta, como o próprio autor relata, foi escrita em "rápidas linhas", agradecendo genericamente, se comparada às outras cartas, mais afetuosas e detalhadas em sua observação do trabalho de Sidrim, a atuação do arquiteto na obra de sua residência. Ela foi escrita em papel timbrado com elegante monograma próprio $(\mathrm{OL})$, símbolo de distinção social, certamente pelo fluxo de correspondências para membros das Academias das quais era membro e do destacado papel que desempenhava na sociedade, Lima escreve:

Belem 2 de Março de 1926

Prezado amigo Snr. José Sidrim

Agora que terminou a construcção da minha casa e que tudo sahiu a medida dos meus desejos corre-me o dever de enviar-the os meus agradecimentos o que prazeirosamente faço nestas rapidas linhas.

Aproveito a opportunidade para felicital-o pelo seu systema de trabalho por administração que permitte a quem se aventura a edificar nesta terra, agora que os materiaes variam de preço a cada momento, avaliar pessoalmente onde desapparece o dinheiro gastando somente o que quiser e poder gostar.

Rapidez,cuidado,competencia,escrúpulo, delicadeza eis as qualidades que pude reconhecer-the principalmente ao terminar a edificação do meu predio. Reiterando-the os meus agradecimentos abraço-o muito affectuosamente

[assinatura de Orlando Lima] ${ }^{42}$ 

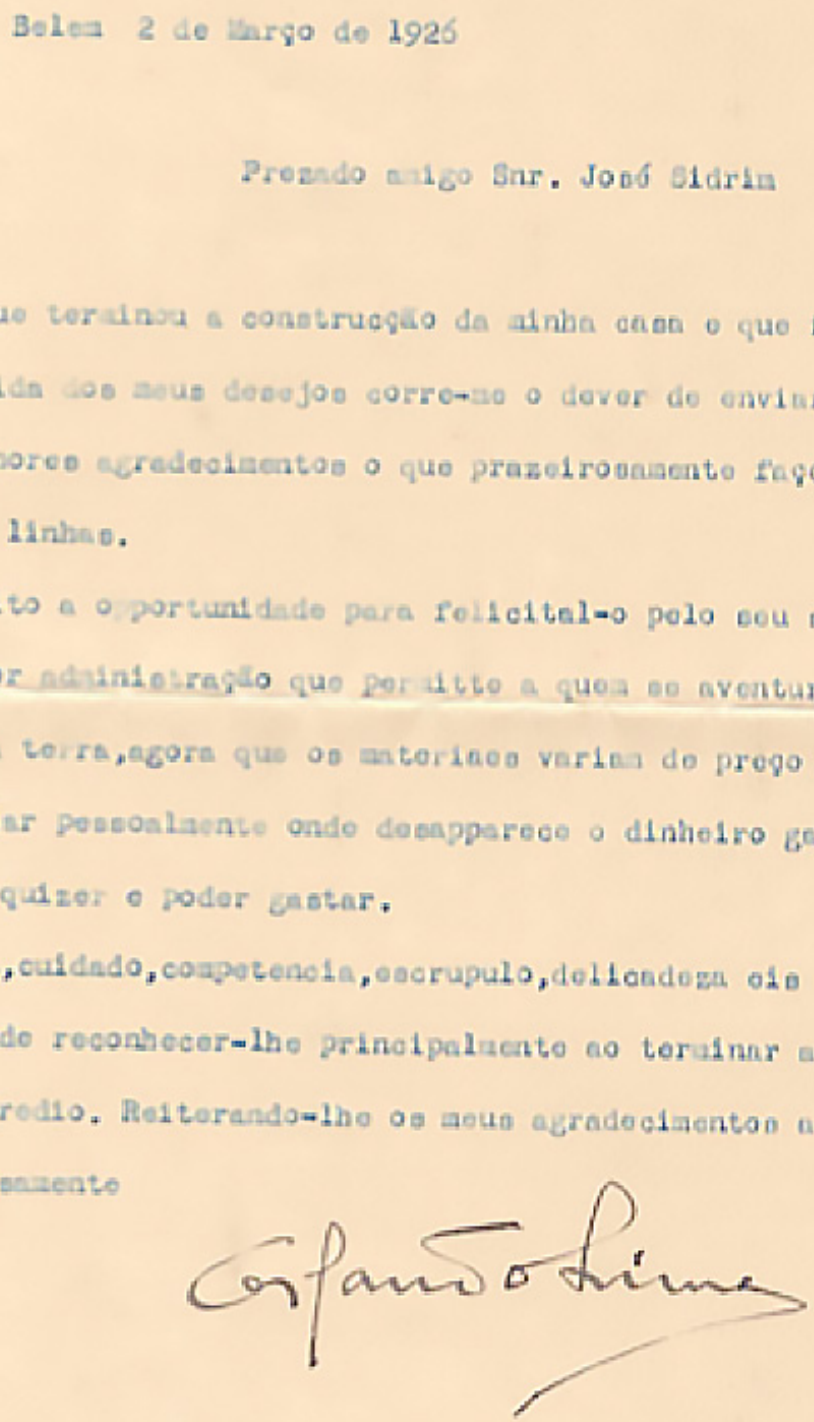

Figura 8 - Carta de Orlando Lima a José Sidrim, de 2 de março de 1926. Fonte: Acervo Ana Léa Nassar Matos. 
Guilherme Paiva era engenheiro civil, formado em Paris, ${ }^{43}$ gerente geral da Port of Pará entre 1916 e $1940^{44}$ - uma das maiores empresas de Belém no início do século XX, concessionária do porto da cidade e em que também trabalhou Sidrim logo que chegou à cidade. $\bigcirc$ palacete que pertenceu ao engenheiro data de 1924, sendo o primeiro, dentre os três apresentados neste artigo, a ser construído. $\bigcirc$ lote em que o prédio está inserido possui grandes dimensões, garantindo afastamento em todas as faces e possibilitando a existência de um grande jardim ao fundo. Além da residência, o prédio possui uma edícula em anexo que funciona como garagem e residência dos funcionários. A presença de edículas em casas de grande porte é recorrente na tipologia de palacetes durante as primeiras décadas do século XX.

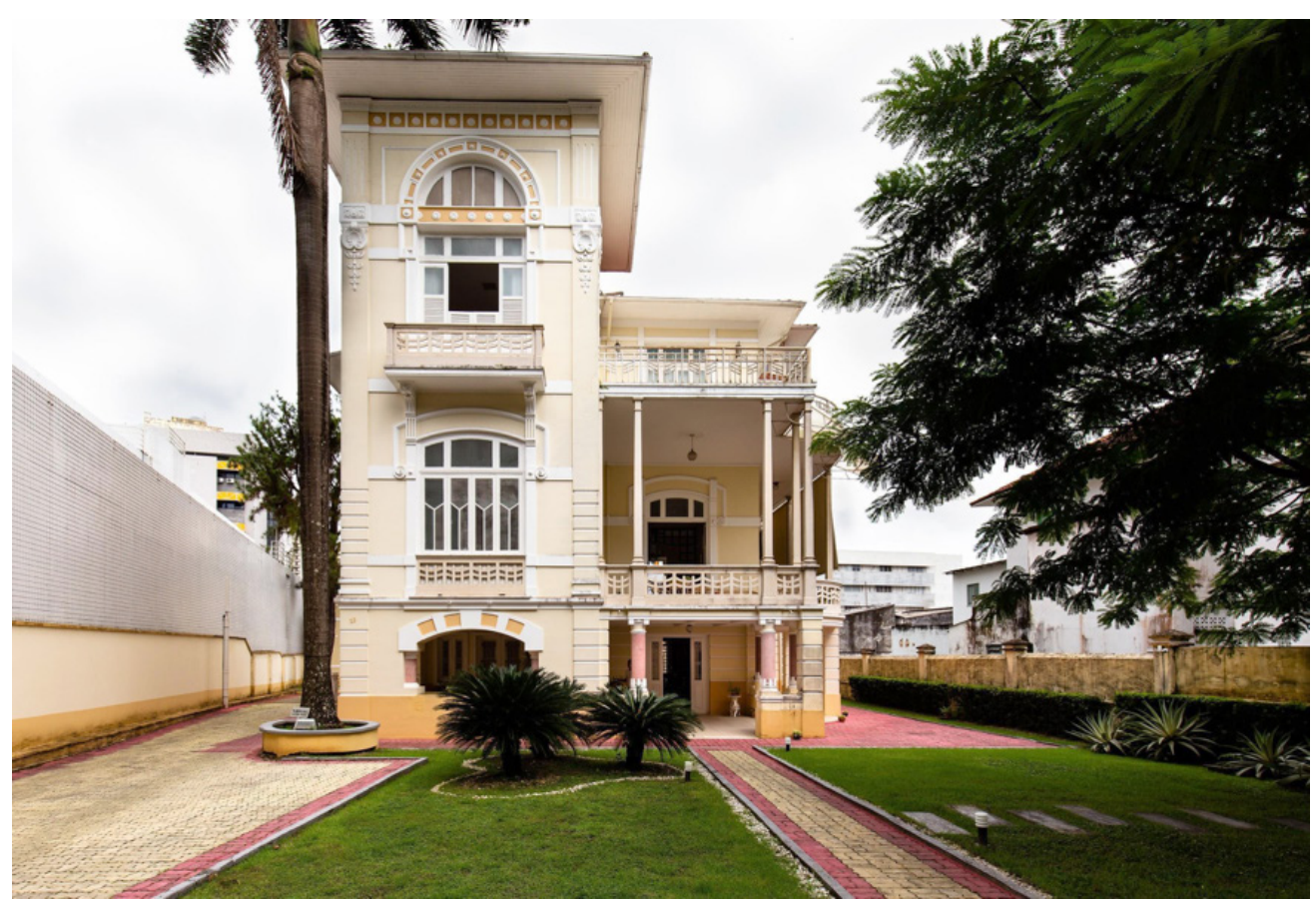

Figura 9 - Fachada frontal do Palacete Guilherme Paiva, destaque para o grande recuo frontal da residência e os vidros canelados das janelas em arco. Foto: Armin Mathis.

ecletismo, com forte influência das "vilas italianas", 45 é o estilo adotado para o palacete, identificado pela inclinação dos telhados e pelo uso de materiais como granilite, vidros coloridos nas janelas, madeira nas esquadrias e condutores aparentes em ferro. Característico do estilo neoclássico, o jogo de volumes nas fachadas através das varandas é destaque, bem como os vãos que recebem
44. Há exposto, na sede da atual Companhia das Docas do Pará (CDP), antiga Port of Pará, uma fotografia de Guilherme Paiva em que o cargo de gerente geral e o período em que ocupou tal cargo constam na moldura. Agradecemos à professora Marcia Nunes (UNAMA) pela gentileza do intermédio com funcionários da CDP que permitiram o acesso à fotografia.

45. Dentre as correntes estilísticas residenciais que influenciaram o Ecletismo no Brasil, destacam-se as da França e da Itália (PATETTA, 1987 , p. 13). 
diferentes tratamentos a depender do seu grau de importância: o pavimento térreo possui vergas retas, o primeiro pavimento possui vergas em arco abatido, e o segundo pavimento, por fim, possui vergas em arco pleno.

programa de necessidades é bastante tradicional ao padrão das residências ecléticas. $\bigcirc$ pavimento térreo atua como ala masculina do palacete, destinado a receber e trabalhar, devido à presença de uma sala de jogos, uma sala de estar e um gabinete. Já o primeiro pavimento apresenta ambientes sociais como sala de jantar, sala de música e varanda, além de espaçosa cozinha, copa e sala de almoço. $\bigcirc$ segundo pavimento, apesar do grande tamanho, destina-se exclusivamente ao casal: apresenta apenas quarto, quarto de vestir, saleta e casa de banho. Um diferencial deste programa distributivo é um mirante na cobertura, pedido especial do proprietário, com a finalidade de observar a chegada dos navios aos portos da cidade.

Paiva reitera o caráter espontâneo em que escreve a carta (Figura 10), o que percebemos diferir do tom da carta escrita por Orlando Lima (Figura 8). Além disso, aborda a economia na construção: por ser engenheiro civil e gerente da Port of Pará por 24 anos, certamente o quesito econômico das obras o era bastante importante - o que faz com que este elogio também funcione como uma outorga explícita, um reconhecimento público das competências administrativas do arquiteto José Sidrim. Em papel timbrado da Port of Pará, com o logo da empresa rasurado, tornando o documento uma carta pessoal e não profissional, Paiva escreve:

24 de Agosto de 1926.

$\| m^{\circ}$ Snr. Dr. José Sidrin,

Presente.

No momento em que me são entregues por V.S. as chaves de minha nova residencia, sita á Travessa Dr. Moraes n² 26, cujo plano e construção obedeceram á criteriosa competencia de V.S., é com a maior satisfação que venho the agradecer a dedicação com que se houve na realisação dessa obra. A espontaneidade com que gostosamente the dirijo estas linhas the dá a prova mais cabal do meu contentamento, não só sob o ponto de vista architectural que apresenta o novo predio, o que é por todos reconhecido, como tambem no que diz respeito á economia realizada em sua construcção. Aliás, outra coisa não se podia esperar de sua competencia como profissional distincto cuja fama cada vez mais se affirma em nosso meio.

Com os meus sinceros agradecimentos, queira acceitar as affectuosas saudações do

Collega que muito o estima,

[assinatura de Guilherme Paiva] ${ }^{46}$ 


\title{
PORT OF PAPA
}

CAIXA POSTAL No. 469

PARÁ.

BRAZIL.

24 de Asouto de 2026.

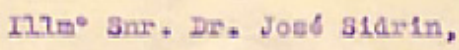

\section{Regasente.}

Ilo romonto on quo to at̃o entreguea por V.S. ae oraves de minhe nove posidenola, atte a zravosed Dr. Mtornes $\mathrm{n}^{\circ} \mathrm{26}$, ougo

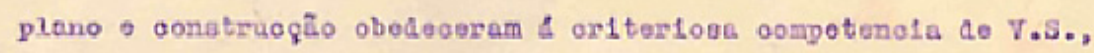
6 oom a mator batiofequio quo vonho tho egredeoer a dea1oagĩo oom que be houre na resl1espto đeses obre. A espontenotdede o om que Bostosemonte the atrijo eatas I1nhas the dif a prova melo asbal do moru oontentamento, nïo ab uob o ponto do viata arohiteotural que apresents o novo prodio, o gue o por todos reoonheoldo, oomo tamben no que 41 z reapelto \& economla roskizoda om sus oonotruo-

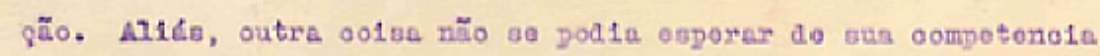
gomo proflestonal diotinoto ouja famn oada ves mela so, efrima อำ म0830 mo10.

Cos os mous olnoeros agredeofaentod, quofra aooettar eq affeotuosas usudsçőes do

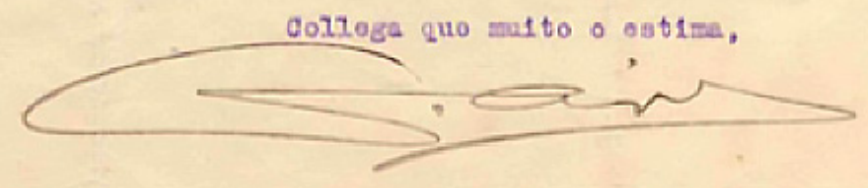

Figura 10: Carta de Guilherme Paiva a José Sidrim, de 24 de agosto de 1926. Fonte: Acervo Ana Léa Nassar Matos. 
47. "O palacete Passarinho, onde o dr. Getulio Vargas ficará hospedado, está dotado de todas as commodidaes, nelle existindo uma sala telegraphica, com installações Morse e de radio; uma sala para o serviço de imprensa e varios gabinetes para trabalho. Foram installados, nos varios compartimentos do palecete, 18 telephones. Todo o edificio será profusamente iluminado. A fachada está coberta de lampadas electricas" (CORREIO DA MANHÃ, 1933, p. 13). Os jornais Diário Carioca, O Jornal e Diário do Norte, todos do Rio de Janeiro, também publicaram matérias sobre a estadia do Chefe do Governo Provisório no Palacete Passarinho. Coletânea dessas informações no Blog da FAU UFPA (PALACETE PASSARINHO, 2016).

\section{Benedicto Passarinho}

Benedicto Passarinho, empresário e farmacêutico, é o proprietário da última residência projetada e executada por José Sidrim e sua equipe. O Palacete Aurélia Passarinho, nome em homenagem à mulher de Benedicto, é, segundo o historiador Augusto Meira Filho, o favorito do arquiteto. Com a obra finalizada em 1927, o prédio está inserido em área de expansão da cidade, na Av. Independência (hoje Av. Magalhães Barata), no bairro de São Brás. Assim como os outros personagens aqui apresentados, Benedicto e sua família também possuíam relação direta com os moldes europeus de morar, visto que, no período da construção da residência, suas duas filhas estudavam em um colégio na França. Aurélia e Benedicto eram um importante casal na cena social da cidade e, por isso, utilizavam a residência como local para receber amigos, festejar os momentos importantes e hospedar destacadas personalidades da história do Pará e do Brasil, como o então presidente Getúlio Vargas em setembro de 1933.47

$\bigcirc$ arquiteto Sidrim, seguindo os desejos dos proprietários, traçou o partido inicial do palacete de modo a abrigar um complexo programa de necessidades e funções que, além da residência, seria também composto por um jardim francês e uma edícula cujo objetivo seria abrigar a garagem e a dependência dos empregados.

Mais setorizada que as anteriores, a casa possui um baldrame de aproximadamente $70 \mathrm{~cm}$ que eleva o pavimento térreo a primeiro pavimento, constituído pelos setores sociais e de serviços. Neste, a presença do vestíbulo recebe o maior destaque por ser primeiro ambiente da residência e responsável por interligar todo o setor social. Por fim, aos fundos, está o setor de serviço. Já nos pavimentos superiores, segundo e terceiro, o setor íntimo ocupa quase todo o espaço. $\bigcirc$ grande diferencial deste palacete é a utilização de parte considerável de seus revestimentos importados da França, assim como todas as louças e metais dos banheiros.

Percebe-se pelo texto da carta uma menor formalidade, o que demonstra um maior grau de admiração e de amizade entre o proprietário-autor e o arquitetoconstrutor. Amizade esta que resultou na entrega de uma chave de ouro do Palacete a Benedicto no momento de finalização da obra (Figura 12). 


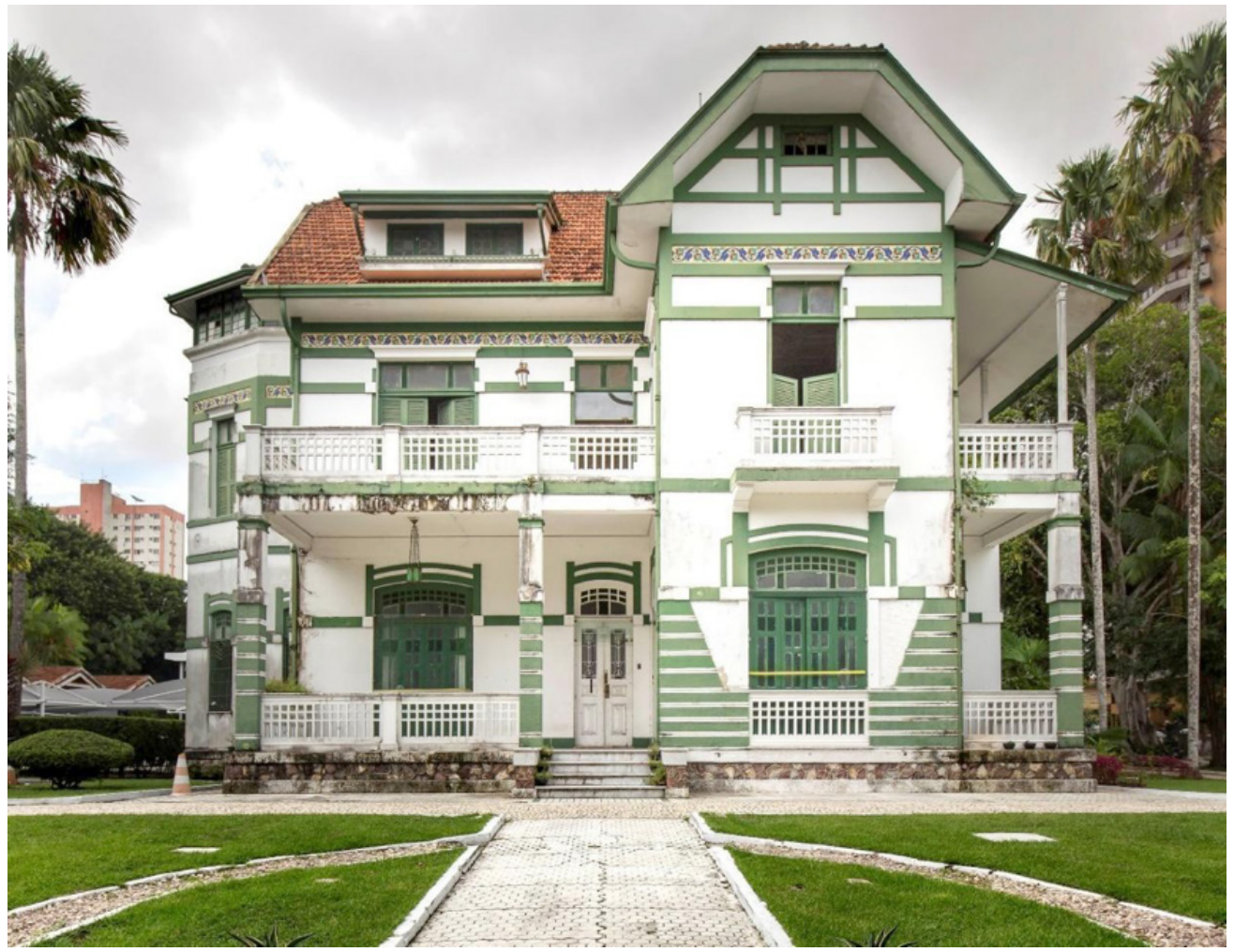

Figura 11 - Palacete Aurélia Passarinho, residência eclética com ladrilhos hidráulicos na fachada importados da França. Foto: Armin Mathis.

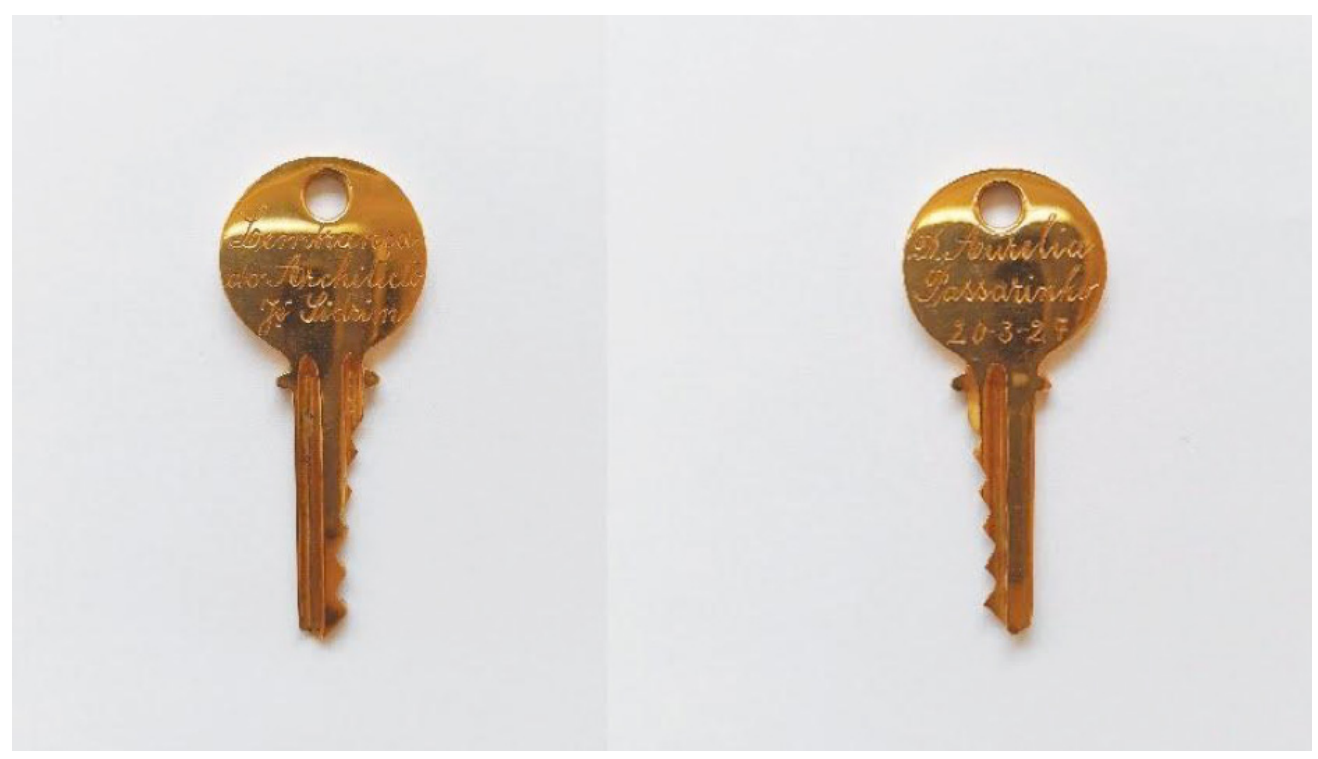

Figura 12 - Chave entregue à Família Passarinho, com escrito gravado "Lembrança do Architecto Jé Sidrim" e "D. Aurélia Passarinho 20-3-1927", ainda sob posse da família. Foto: Pietra Paes Barreto. 
Além de gratidão ao arquiteto, Benedicto também demonstra seu encantamento com o resultado entregue, sobretudo, ao tratar da precisão do trabalho de Sidrim e de seu rigor técnico em relação à problemática climática da região. $\bigcirc$ empresário continua sua carta registrando também os agradecimentos de sua esposa ao arquiteto. Por fim, é destacada a dedicação e o afeto do arquiteto com o seu trabalho.

Umas das particularidades da carta apresentada abaixo é que o autor não aborda apenas aspectos estéticos, mas destaca, inclusive, os aspectos técnicos do projeto. Cita o cuidado do arquiteto em tratar com rigor as questões higiênicas e de conforto ambiental, sabendo adequar o projeto aos padrões europeus para o clima quente e úmido da Amazônia ao garantir a presença de aberturas em todos os ambientes que proporcionam ventilação cruzada.

Amigo Dr. José Sidrim

Ao receber ultimada a casa No 60 á Avenida Independencia, cujo projecto e construcção confiei ao vosso criterio e responsabilidade profissionaes, tenho o prazer de trazer-vos meus agradecimentos e louvores que mal podem estas linhas traduzir e que resultam do integral e optimo desempenho do vosso compromisso.

Desde a sala ao ultimo desvão do predio não encontrei um só defeito, uma só falha, um só pecado. A robuste dos alicerces, a exatidão estereoromica dos travejamentos, o equilibrio rigorosamente geometrico do arcabouço, a impecavel inflexibilidade das arestas, as rigidas juncções, as minucias dos remates perfeitos; a disposição divisional atendendo as exigencias da Hygiene e do conforto pertinentes ao nosso clima, traduzem o technico rigoroso.

O traçado do aspecto geral, da flecha á base, a graça das proporções, a elegante singeleza das linhas ornamentaes, os motivos decorativos, as subtilezas dos mínimos promenores, conjuncto em que haveis aproveitado todos os elementos expressivos da harmonia architetonica, - caracterizam o artista.

Vê-se em tudo, - mais ainda - sente-se o meticuloso e paciente esmero o perseverante esforço, o carinho que tende pela vossa arte, o anceio pelo melhor, o amor pela perfeição, a tortura da pesquiza dos rhythmos da belleza - cunho dos vossos trabalhos assignalados de espiritualidade.

Estou plenamente satisfeito e assim, estas palavras que ahi ficam, não representam uma formula banal de cortesia mas caracterisam-se pela sinceridade devida por sobejas razões.

Minha esposa, pede para que vos signifique egualmente o seu contentamento e os seus elogios.

Com os meus melhores cumprimentos,

Compatricio e amigo

Belem, 16/4/27 [assinatura de Benedicto Cesar Santos Passarinho] ${ }^{48}$ 


\section{Lineo De. Jost stdrie}

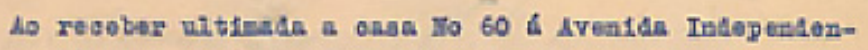

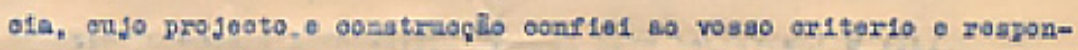

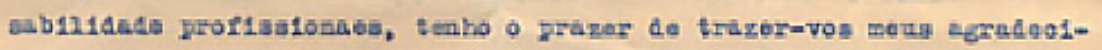

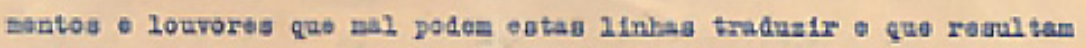

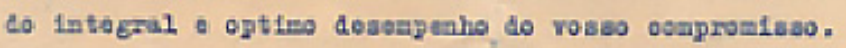

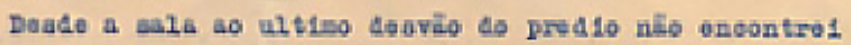

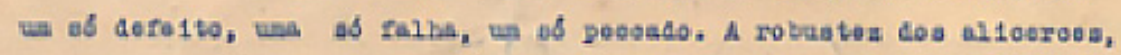

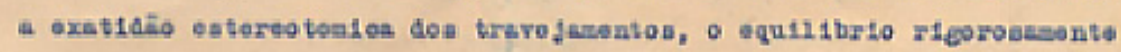

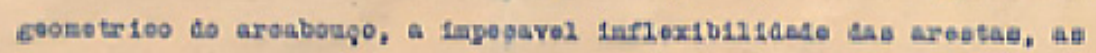

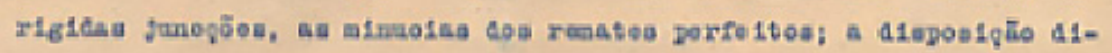

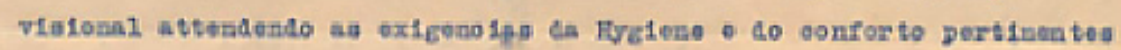

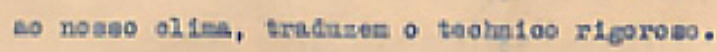

0 tragndo do avpoato gomi, da noma 4 baga, A grage

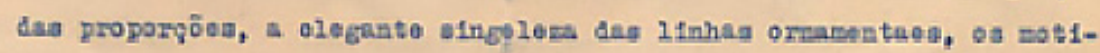

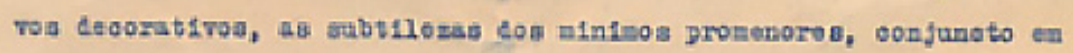
que bavolo aproveitsdo todoe os elementol expreasirou da hareasa arelitetonica, - gareterisas o artiata.

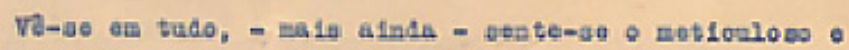

pateate easero o peraeverante eaforpge, o earimho que tondas pela vos-

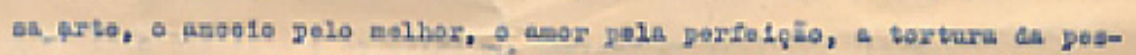

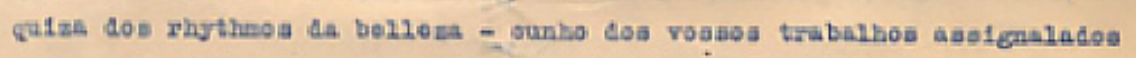
de ooplritualdate.

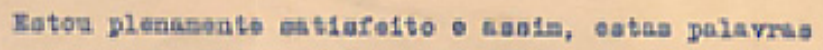

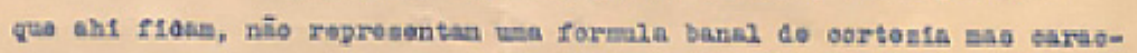

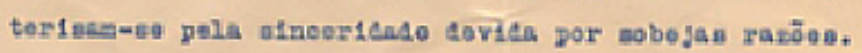

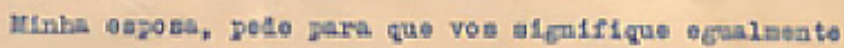

o sou contartamento o go sou ologios.

Be1en, 16/4/87

Com os meas meyores ouprinontos ,

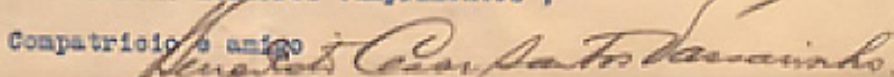

Figura 13 - Carta de Benedicto Passarinho a José Sidrim, de 16 de abril de 1927. Fonte: Acervo Ana Léa Nassar Matos. 
50. Deleuze (2015, p. 1).

51. Foucault (1986, p. 84)

52. Eiró (2014).

\section{CONSIDERAÇÕES FINAIS}

Escolhemos abordar a repercussão da atuação de Sidrim no meio em que vivia através da análise de discurso das cartas, pois tal matriz historiográfica permite incluir e analisar os aspectos históricos, sociais e afetivos que a arquitetura pode desempenhar. Destacamos também o próprio caráter linguístico das cartas a partir de sua materialidade léxica e simbólica. $\bigcirc$ autor, ao operar e escolher as palavras, manipula referências que elencou afetivamente e compõe seus relatos pessoais de modo semelhante ao que Sidrim operou nos campos da imagem e do objeto arquitetônico. Tudo, então, é linguagem - ou "tudo é projeto", como diria Paulo Mendes da Rocha. Partimos do pressuposto de que os efeitos arquitetônicos - neste caso, as cartas - estão no mesmo patamar que a própria obra arquitetônica, pois tratam precisamente do mesmo processo de grafia dos afetos, sejam eles imagens ou palavras.

O fato de existirem cartas sobre objetos arquitetônicos mostram um ponto de inflexão no qual a arquitetura passa a ser um campo na natureza da linguagem. Esta escolha de abordagem metodológica do objeto a partir do seu caráter fenomenológico e subjetivo permite compreender o fluxo complexo e ambíguo dos elementos semiológicos e comunicativos no qual a linguagem passa por um processo de escrileitura em que se lê e se escreve ao mesmo tempo - em que se lê escrevendo ou se escreve lendo. A arquitetura, então, funciona no mesmo sentido da escrileitura. Quem lê a obra arquitetônica - assim como quem lê um texto ou uma imagem - passa pelo processo fenomenológico de compor sua experiência do objeto a partir de suas próprias vivências, referências e parâmetros afetivos pessoais. Quem compõe a obra arquitetônica (ou historiográfica ${ }^{49}$ ) faz o mesmo: a partir da leitura de outras obras, textos e imagens, opera na criação de algo próprio. O fluxo comunicacional, inclusive no campo da arquitetura, é um vetor duplo de modo que os efeitos arquitetônicos são paradoxais, pois afirmam os dois sentidos ao mesmo tempo..$^{50}$

Neste trabalho, não propomos uma análise das etapas finais dos objetos, nem da gramática ou da organização retórica das cartas, nem das composições ornamentais e dos elementos estruturais das residências; mas das modalidades de enunciação, ${ }^{51}$ das operações compositivas através da memória, dos movimentos de imagens e de afetos. ${ }^{52}$ Além da similaridade arquitetônica e temporal entre os três palacetes, o fato de seus proprietários terem escrito uma carta de agradecimento ao arquiteto José Sidrim demonstra, por fim, o poder social da palavra. 


\title{
REFERENCIAS
}

FONTES MANUSCRITAS

LIMA, Orlando. [Correspondência]. Destinatário: José Sidrim. Belém, 2 mar. 1926. 1 carta.

PAIVA, Guilherme. [Correspondência]. Destinatário: José Sidrim. Belém, 24 ago. 1926. 1 carta.

PASSARINHO, Benedicto. [Correspondência]. Destinatário: José Sidrim. Belém, 16 abr. 1927. 1 carta.

\author{
FONTES IMPRESSAS
}

CORREIO da Manhã, Rio de Janeiro, ano 33, n. 11.882, 26 ago. 1933.

JORNAL Estado do Pará: Propriedade de uma Associação Anonyma, Belém, ano 4, n. 1119,6 maio 1914. Fundação Biblioteca Nacional, Hemeroteca Digital Brasileira.

O PAIZ, Rio de Janeiro, ano 57, n. 15.032, 16 dez. 1925. Fundação Biblioteca Nacional, Hemeroteca Digital Brasileira.

LIVROS, ARTIGOS E TESES

ALCÂNTARA, Dora; BRITO, Stella; SANJAD, Thais. Azulejaria em Belém do Pará: Inventário - Arquitetura civil e religiosa - Século XVIII ao XX. Brasília: IPHAN, 2016.

BAHIA, Carmosina Maria Calliari. Uma Análise Etnográfica na Memória e Cotidiano na Avenida Governador José Magalhães Barata, Belém - Pará. Tese (Mestrado em Arquitetura e Urbanismo) - Universidade Federal do Pará, Belém, 2016.

BARTHES, Roland. Fragmentos de um discurso amoroso. São Paulo: Editora Unesp, 2018.

BARTHES, Roland. A câmara clara: Nota sobre a fotografia. Rio de Janeiro: Nova Fronteira, 2017.

BARTHES, Roland. Sade, Fourier, Loyola. São Paulo: Martins Fontes, 2005.

BARTHES, Roland. La chamber claire: Note sur la photographie. Paris: Gallimard/Seuil, 1980. 
BELÉM da Saudade: a memória de Belém do início do século em cartões-postais. Belém: SECULT, 1998.

CASTRO, Fabio Fonseca de. A cidade Sebastiana: era da borracha, memória e melancolia numa capital da periferia da modernidade. Belém: Edições do autor, 2010.

CENCETTI, Giorgio. Vecchi e nuovi orientamenti nello studio della paleografia. La Bibliofilía, Firenze, v. 50, n. 1, p. 4-23, 1948.

DELEUZE, Gilles. Lógica do sentido. São Paulo: Perspectiva, 2015.

DELEUZE, Gilles. Cinema II: A Imagem-tempo. São Paulo: Brasiliense, 2007.

DELEUZE, Gilles; GUATTARI, Félix. O que é a filosofia? Rio de Janeiro: Editora 34, 1992.

EIRÓ, Jorge. Arquitextura dos afetos: escrileituras sobre desenhos de artistas-professores. 2014. Tese (Doutorado em Educação) - Programa de Pós-Graduação em Educação, Universidade Federal do Pará, Belém, 2014.

FIGUEIREDO, Aldrin Moura de. No tempo dos seringais: o cotidiano e a sociedade da borracha. São Paulo: Atual, 1997.

FOUCAULT, Michel. A arqueologia do saber. Rio de Janeiro: Forense, 1986.

GÓMEZ, Antonio Castillo; SÁEZ, Carlos. Paleografia versus Alfabetização. Reflexões sobre História Social da Cultura Escrita. LaborHistórico, Rio de Janeiro, v. 2, n. 1, p. 164-187, 2016.

GONSALES, Célia Helena Castro. Cidade moderna sobre cidade tradicional: movimento e expansão - parte 2. ArquiTextos, São Paulo, v. 59, n. 4, 2005. Não paginado. Disponível em: <http://bit.ly/2RbNzlf>. Acesso em: 19 ago. 2019.

HAJNAL, István. Le Role social de l'écriture dans les universités médiévales. Scriptorium, Aubervilliers, v. 11, n. 1, p. 3-30, 1957.

LEMOS, Carlos Alberto Cerqueira. A República ensina a morar (melhor). São Paulo: Hucitec, 1999.

LIMA, Kleverson Teodoro de. Cartas, História e Linguagem. Revista de Teoria da História, Goiânia, ano 1, n. 3, p. 210-225, 2010.

LIMA, José Júlio; NUNES, Mateus Carvalho; EIRÓ, Jorge. Cidade, imagem, embelezamento. Desenhos em perspectiva dos planos urbanísticos para Belém. Arquitextos, São Paulo, v. 221, n. 2, 2018. Disponível em: <http://bit.ly/2skdsa7>. Acesso em: 21 ago. 2019. 
MARTINS, Vanessa Gandra Dutra. Reflexão sobre a escrita epistolar como fonte histórica a partir da contribuição da teoria da literatura. Revista Língua E Literatura, Erechim, v. 13, n. 20, p. 61-72, 2011.

MATOS, Ana Léa Nassar. José Sidrim (1881-1969): um capítulo da Biografia de Belém. 2017. Tese (Doutorado em História) - Programa de Pós-Graduação em História, Universidade Federal do Pará, Belém, 2017.

NUNES, Mateus Carvalho. Entre sobrevivência e deslocamentos: a imagem e o fantasma em Aby Warburg. ARTis ON, Lisboa, n. 9, p. 86-96, dez. 2019. Doi: <https://doi.org/10.37935/aion.v0i9.241>.

NUNES, Marcia Cristina Gonçalves. Rumo ao Boulevard da República: entre a cidade imperial e a metrópole republicana. 2017. Tese (Doutorado em História) - Universidade Federal do Pará, Belém, 2017.

OLIVEIRA, Jeová Barros. Do Largo de Nazaré à Praça Santuário: às transformações entre 1982 e 2015. 2015. Dissertação (Mestrado em Arquitetura e Urbanismo) - Programa de PósGraduação em Arquitetura e Urbanismo, Universidade Federal do Pará, Belém, 2015.

PAES BARRETO, Pietra. Reutilização como instrumento de preservação no Palacete Aurélia Passarinho. 2018. Trabalho de Conclusão de Curso (Graduação em Arquitetura e Urbanismo) - Faculdade de Arquitetura e Urbanismo, Universidade Federal do Pará, Belém, 2018.

PATETTA, Luciano. Considerações sobre o Ecletismo na Europa. In: FABRIS, Annateresa (org.). Ecletismo na Arquitetura Brasileira. São Paulo: Nobel, 1987. p. 8-27.

PEREIRA, Sonia Gomes. A Historiografia da Arquitetura Brasileira no Século XIX e os Conceitos de Estilo e Tipologia. 19E20, Rio de Janeiro, v. 2, n. 3, julho de 2007. Não paginado. Disponível em: <https://bit.ly/3cNLIiq>. Acesso em: 17 jun. 2021.

PETRUCCI, Armando; PRATESI, Alessando. Un secolo di Paleografia e Diplomatica (18871986): Per il centenario dell'Istituto di Paleografia dell'Università di Roma. Roma: Gela, 1988.

SARGES, Maria de Nazaré. Belém: Riquezas produzindo a Belle Époque (1870-1910). Belém: Paka-Tatu, 2010.

SARGES, Maria de Nazaré; LACERDA, Franciane Gama (org.). Belém do Pará: história, cultura e cidade - para além dos 400 anos. Belém: Açaí, 2016.

SOARES, Karol Gilet. As Formas de Morar na Belém da Belle Époque (1870-1910). 2008. Dissertação (Mestrado em Arquitetura e Urbanismo) - Programa de Pós-Graduação em História, Universidade Federal do Pará, Belém, 2008.

WAISMAN, Marina. O interior da história: historiografia arquitetônica para uso de latinoamericanos. São Paulo: Perspectiva, 2013. 
SITES

PALACETE Passarinho: "residência provisória" de Getúlio Vargas - 1933. Blog da FAU UFPA, Belém, 5 ago. 2016. Disponível em: <http://bit.ly/35QZcDE>. Acesso em: 12 ago. 2018.

ENTREVISTA

MATOS, Ana Léa Nassar. [Entrevista cedida aos autores]. Belém, 17 mai. 2019, por telefonema.

Artigo apresentado em: 10/09/2020. Aprovado em: 02/03/2021.

\section{(c) BY}

All the contents of this journal, except where otherwise noted, is licensed under a Creative Commons Attribution License 